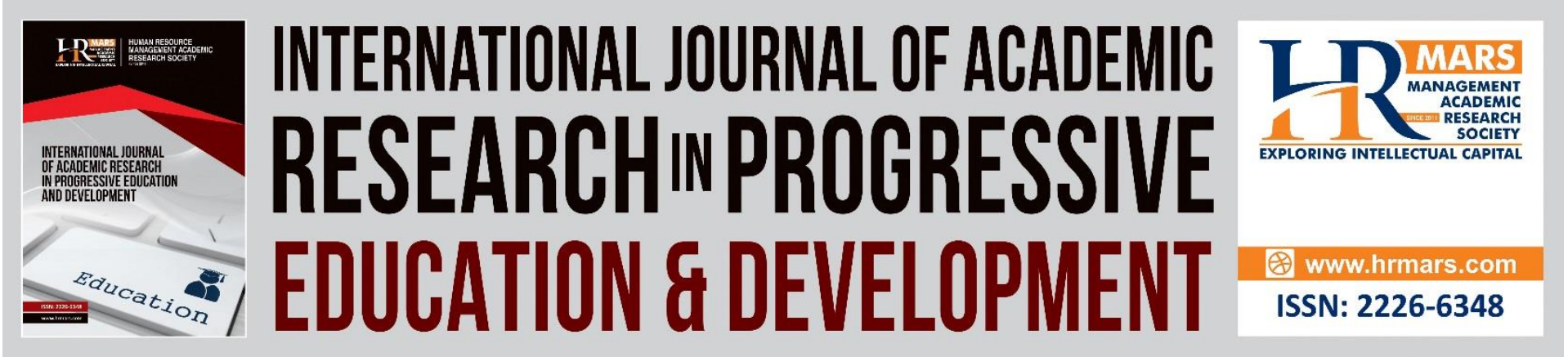

\title{
Parental Style and Academic Achievement in Mts Ittihadul Muslimin Siak Students
}

\author{
Najmi Hayati, M. Ali Noer
}

To Link this Article: http://dx.doi.org/10.6007/IJARPED/v10-i4/11840

DOI:10.6007/IJARPED/v10-i4/11840

Received: 08 September 2021, Revised: 13 October 2021, Accepted: 26 October 2021

Published Online: 20 November 2021

In-Text Citation: (Hayati \& Noer, 2021)

To Cite this Article: Hayati, N., \& Noer, M. A. (2021). Parental Style and Academic Achievement in Mts Ittihadul Muslimin Siak Students. International Journal of Academic Research in Progressive Education and Development, 10(4), 29-45.

Copyright: (C) 2021 The Author(s)

Published by Human Resource Management Academic Research Society (www.hrmars.com)

This article is published under the Creative Commons Attribution (CC BY 4.0) license. Anyone may reproduce, distribute, translate and create derivative works of this article (for both commercial and non-commercial purposes), subject to full attribution to the original publication and authors. The full terms of this license may be seen

at: http://creativecommons.org/licences/by/4.0/legalcode

Vol. 10(4) 2021, Pg. 29 - 45

http://hrmars.com/index.php/pages/detail/IJARPED

JOURNAL HOMEPAGE

Full Terms \& Conditions of access and use can be found at http://hrmars.com/index.php/pages/detail/publication-ethics 


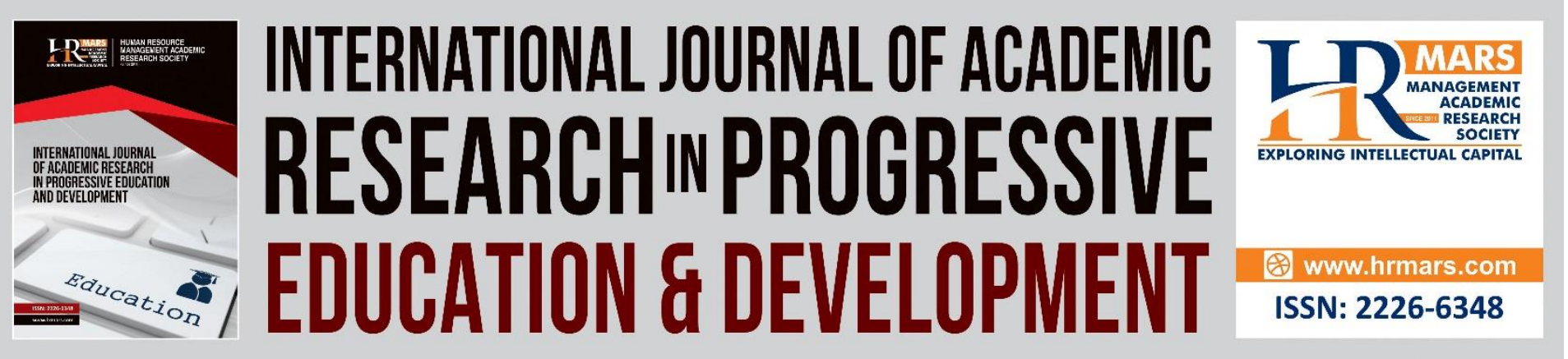

\title{
Parental Style and Academic Achievement in Mts Ittihadul Muslimin Siak Students
}

\author{
Najmi Hayati, M. Ali Noer \\ Institute for Research and Community Service, Universitas Islam Riau
}

\begin{abstract}
Pangkalan Pisang Village is located in the Koto Gasib District of the Siak Regency in the Indonesian province of Riau and the study was carried out there. The aim of this research was to determine whether or not there was a relationship between parenting styles and student learning accomplishments in second grade (class 2). Students at MTs Ittihadul Muslimin will be asked to respond to a questionnaire, and the results will be compiled. When this performance is reduced, it indicates the necessity of developing classroom instructional techniques that include academic components, social relationships and conduct as well as other factors. Immediate summaries of student accomplishments, as well as measures to enhance student participation, motivation, and success, should be provided. Thus, personality differences and students' skills are less significant than they were previously believed. In the absence of consideration for the connection between student cognitive types, parents develop their own parenting styles, with the consequence that parenting styles and learning are the outcome of the style of parents and students'. Researchers Omar et al (2012) found that parental influence is the most important factor in a child's development as a human being. Diana Baumrind is credited with developing the parenting style model (Omar et al., 2012). As he explained it, there are three types of parenting techniques that may be used to shape children's early development. Parents who practice autority, authoritarian parenting, and permissive parenting are examples of parenting styles that are related to the authorization style. Measurements of the average and standard deviation are used to characterize the respondent profile and to answer research questions using descriptive statistical analysis. According to this research, the most prevalent parenting style is autiithative. Thus, the appropriate parenting style is the most apparent in the parenting styles of all tribes, including Malay, Minang, Java and Batak families. Because it does not fully understand the parenting style of each individual, his understanding is that the parenting style of Diana Baumrind is also not used optimally by parents. He believes that parents must understand their own parenting style in order to harmonize with the requirements of how to educate their children. It was discovered in this research that even if the interpretation is straightforward, the authoritarian and permissive styles have a beneficial impact on students' academic performance when used in conjunction with one another. Nevertheless, the autorithative style is the most often employed since it is seen as more intimate and harmonious by youngsters, and therefore is frequently used.
\end{abstract}


Keyword: Parenting Style, Culture, Student, Achievement, Academic.

\section{Introduction}

The discussion in the parent's surroundings is mostly focused on the accomplishments of their children, which is understandable. Because academic success in kids is still measured in terms of high numbers with meaning, if a student has a high academic value, the student is regarded to be exceptionally bright at this time. The school is, after all, a formal organization that must answer for the accomplishments of its pupils. The function of the family, on the other hand, is very essential since parents are the first teachers of their children. As a result, parents must constantly lead their children toward positive ideas and values in order to create an environment conducive to learning.

According to Harun (2007), the family is the foundation of a society that has interaction between the cognitive and emotional sides, as well as between the two. According to Omar et al (2012), parents are the most important source in the process of developing a child's personality. Relationships that are very close to someone's personal life are referred to as "family" (Zin, 2005). According to Omar (2008), the growth and creation of families in a society will be a deciding element in the building of a country, and developing nations need a high-quality individual family unit to be successful (Baba, 2007). This parent is not only connected to a kid by blood and blood terting, but they are also extremely intimately involved in the child's social and emotional integration as well (Nurdiani, 2019). Yahya (2007), belief that a family teaches their children does not have a positive effect on the person in a formal sense.

Parenting styles that are inherent in each family may be developed via training to create the desired style in conjunction with the activities carried out, or they can be developed through the experiences that the family has acquired. Despite this, each member of the family has developed their own personal style. Of course, in order to achieve a better style, which may be harmonic or can be harmonious between parental and student styles, there must be an increase in the income of information, experience, and the environment in which they are to be practiced.

\section{Parenting Style}

Parents serve as positive role models for their children. Early childhood education takes place in the home. Student achievement in school and future success in life will be largely dependent on the motivation and support of their families (Zulkifli et al., 2011). The foundation of any good education for the younger generation is the family (Bakar, 2007).

In this research, the Parenting Baumrind style model was utilized to describe the parenting style of the participants. This idea serves as the foundation for the research reference in this article. Diana Baumrind was the first to propose a model of parenting style (Omar, Manaf \& Ayob, 2012). He said that there are three types of parenting techniques that may be used in the early development of children. There are three parenting styles that are related to the authorization style: autority, authoritarian, and permissive parenting.

Parents have a very important role in the lives of their children. According to him, one of the qualifying qualities of parents who want to be remembered as memorable parents is that they provide a good example for their children. Children need someone who they can look up to, and experts believe that parents must act and apply the values that are anticipated to produce successful children (Norsayyidatina, 2011). According to the remark of Oryan \& Gastil (2013), 
parents must also understand the nature of their duty for their children, since people are not born with the knowledge of how to be someone who is responsible.

According to Elias \& Yee (2009), many individuals believe that parenting is a difficult task. Parenting style is one of the aspects of human development that has been extensively researched (Baldwin, McLntyre \& Hardaway, 2007). However, every parent or country has a distinct approach to child care or parenting methods. Nurdiani, 2019. Parenting methods are also affected by the behaviors of the children (Zin, 2005). This remark is backed by Munji \& Redzuan (1990), who say that parents who have mature and competent children may be intimate with them, love them, communicate with them effectively, accept the child's point of view without compromising firmness, and be attentive to their conduct. Children who are deemed suitable for the situation.

Parenting Style Variables may vary depending on a variety of reasons, such as age, gender, culture, environment, individual stage of religion, educational level, and a variety of other factors (Rathakrishnan \& Rahim, 2008).

\section{Parenting Style: Authoritatif}

Parents that use the autority parenting style will encourage their children to be physically active while still limiting and controlling their activities. Parents should be nice with their children, but they must also be stern with them. If there is a family rule that is strictly enforced. Parents utilize their logical and seductive brains to entice cooperation from their offspring. They educate youngsters on the rules, and children are encouraged to express themselves freely. Children are informed of the limits on their conduct and the limitations on their independence based on their age.

The authority style, according to Zin (2005), is characterized by parents who tend to give birth to self-friendly children who are excellent at adapting and being innovative, as well as parents who place a great emphasis on distinguishing assertive from hostile behavior. According to Fabes \& Martin (2003), the parents of the authority are highly receptive and have high expectations. They show respect for children by engaging themselves in family issues and as decision-makers, encouraging the development of self-behavior, and stressing the importance of responsibility. (Clark \& Shields, 1997; Sokol-Katz \& colleagues, 1997; Yahaya \& Bahari, 2010) who participated in authority's parents observed and always had an attitude of responsibility to the personal children of their children support this position. The power of rational and democratic parents may later shape children to think favorably, and to continue to be engaged in socializing, behavior and cognitive elements are among the skills acquired. Student success following the outcomes of student academic values, as well as their discipline and student conduct at school, according to Jeynes (2007), is positively related to the authority parenting style, according to the author. The parenting styles of Paternal and Maternal Parenting Style (which are always dominant father or mother) were examined by Ang \& Goh (2006), who found that the parenting authority style had a positive impact on student academic achievement values when compared to the parenting style permissive and the parenting style autoritarian style. However, according to a study conducted by Hines \& Holcomb-McCoy (2013) among African-American male students at two different high schools in the United States, there was no significant connection between parental approaches and student academic performance. 
DEVELOPMENT

Vol. 10, No. 4, 2021, E-ISSN: 2226-6348 @ 2021 HRMARS

\section{Parenting Style: Autoritarian}

According to Baumrind (1989), authoritarian parents employ stages by offering instruction on how they must be done by children on a daily basis, and they do not have a sense of responsibility for anything, even if it is just explaining why children must follow the direction given. Parents that have an authoritarian style are very demanding on their children and do not respond to their children's needs. They are more likely to have children who obey and obey the demands of the rules. If there are children who are not obeying the rules, their parents will discipline them. This practice of having an open talk between children and parents is not carried out after the child complies with the parents' regulations because these parents believe that the child should not ask any questions and should simply accept and obey all of the direction and instruction of the parents. Fabes \& Martin (2003) also explain that authoritarian parents will form, control, and judge all of their children's behavior and attitudes in accordance with strictly good marawan, where parents teach children absolute rules and absolute behavior without telling them about reasonableness. The researcher believes that education should place a greater emphasis on punishment and behaving in accordance with rigorous laws, so that children behave in accordance with the rules rather than taking into account the trust, value, and right of children to express themselves.

\section{Parenting Style: Permisif}

According to Fabes \& Martin (2003), parents who adopted the permissive approach made few demands on their children, according to their research. In response to their children's demands and wishes, they are accepting, tolerant, and understanding. When it comes to achieving goals, committed parents avoid applying pressure. They place a lower emphasis on requirements while placing a higher emphasis on responses.

According to Baumrind (1971), permissive parents give birth to children who are less mature, overly demanding, rebellious, aggressive, and lacking in social competence, as well as children who enjoy following their movements. It is also their preference to make decisions about the authority of children and to flee from responsibility as a person who possesses an authoritative position (Zin, 2005).

Furthermore, according to Bee \& Herman (1995), permissive-shaped styles focus on minor laws while employing acts and power only infrequently. It is almost always the case that parents employ seduction strategies to get their children to behave in a responsible and nice manner. Often, parents appear to disregard their parental responsibilities towards their children. It was because they believe that children can accomplish things for themselves that they allowed them complete independence.

\section{Culture and tradition have an impact on parenting styles}

People from different origins and cultures make up Indonesia's diverse population. This has a significant impact on student behavior because they are not only different from one another on an individual level, such as in terms of gender, privileges, education, and parental care, but they are also different from one another in terms of values, attitudes, and behavior, which may be influenced by their background and cultural background. 
A short definition of culture is the features and outcomes of the behavior seen and analyzed by a group of individuals in relation to their environmental circumstances (Dawi, 2009). According to the statement from Simanjuntak (2009), in the view of the Toba Batak tribe, wealth (Hamoraon), Meriliki Many of Hagabeon (Hagabeon), and honor (Hasangapon) are a system of value in the culture that is also a destination for life that is inherited from one generation to other generations, in a study of six Batak sub tribes, namely Batak Toba, For the Toba Batak culture, there are many values that are important to uphold, and these values are one of the elements that can help Toba Batak teenagers continue to thrive in their studies. We are looking for Irmawati to join our team (2007).

A Riau Malay is someone who comes from the island of Riau. The group's public relations efforts with the community are successful. In general, Malay culture is welcoming and friendly, which describes the Riau Malay population as a whole. Religion serves as the foundation of Malay civilisation. According to traditional Malay philosophy, "Adat drains Syarak, Syryly drives the book," according to traditional Malay philosophy, which means that Malays who adhere to the Book of Allah and the Prophet Sunah are "draining Syarak, Syryly driving the book" (Suwardi, 2007). The Malay proverb that goes "Let the infant perish among the indigenous children," as the Malay proverb goes, demonstrates how much they believe in customs. "Customary is not heated by heat, and it is not weathered by rain," says the second phrase. In addition, there is a saying that "once a single tepian changes," which means that imagined customs should not be adapted to the eras in which they are created (Suwardi, 2007). It is the ideals that constitute culture that are at its heart or at its core. It is the cultural values that define the character and pattern of the mind, as well as the manner of thinking and human behavior in a culture, that constitute the essence of that culture.

Many studies have been conducted in the Malay community, and the results are available. Bee does extensive research on any topic (1995). According to the findings of the study, Malay people's parents seldom serve since their children prefer to seek their mother for help. According to Bee, the Malay community does not have enough questions to ask their children, and they do not teach their children about studies and education too often. Indirectly, they demonstrate to parents in Malay society that they are less concerned with education for their children. This is a deficiency in the mastery of Malay youngsters in the realm of lessons that has to be addressed.

Syukur (2012) describes the Social Relations of the Javanese people that have developed as a result of the existence of Tepo Seliro, which means that they measure themselves against themselves and not against others. This advice might be taken as meaning that others should not do an act on another person that they do not want to be performed by themselves, that others should not be injured, and that others should not interfere with other people's issues. Sedyawati (2010) describes the Javanese point of view, which is that the conduct of individuals related to the Javanese people is taken into consideration by the Javanese people. According to Sedyawati (2010), in the Javanese tribe, improper or inappropriate behavior (ora) is regarded as a symptom of inadequacy and should be avoided. It is necessary to follow procedures in the use of language and greeting, how the technique for taking the body's attitude is also a method of self-placement, clothing procedures, and other procedures. For example, organizing the supported environment and the function of all as a method of forming, planting, and intensifying cultural values in the community are all examples of what we may expect from ourselves. Compliance is the most important value, and only compliance can provide a sense of security (inner receipts). 
Baumrind's research (1967; 1989, as cited in Fabes \& Martin, 2003) discovered that a child's growth is influenced by their parents' parenting style. Non-formal education provided by parents is included in inductive disciplinary methods; moreover, there are autorization styles that include authority and modeling parents in non-formal education. As a sociolization act, it is the responsibility of parents to assist children in the process of developing a positive attitude and healthy values, as well as ensuring that children have a sense of belonging to a community. Children develop a positive attitude toward themselves and have confidence in their abilities when their parents show affection toward them. They can also easily establish social relationships with other people who are advanced in their emotional development as a result of this affection shown by their parents. Parental values and standards of behavior serve as examples for children in the implementation of the values and standards of behavior established by their parents. Parents can teach their children religious discipline and pure values by rewarding them when they perform well and punishing them when they perform poorly (Yusof, 2000).

\section{Methodology}

The researchers will utilize a questionnaire that was administered at the Ittihadul Muslim Pesantren Pangkalan Banang Village, Koto Gasib District, Siak Regency, Riau Province, to gather data for this study. Respondents in the class will work together to answer the questionnaire within a certain time frame. The objective of this phase is to guarantee that respondents in this research complete the questionnaire correctly, and that when there are challenges answering the questionnaire, respondents are able to overcome such difficulties. The results were greatly aided by the honesty of the responders.

In study areas such as culture and tradition, descriptive analysis is utilized to get a general understanding of the subject. The frequency, percentage, mean, and standard deviation are the descriptive statistics that were utilized to solve the problem of parenting styles research. According to Hayes, (2000), information and data obtained from the questionnaire in the form of raw score data will be analyzed using descriptive statistics and interpreted in the form of data that is easier to understand. The descriptive nature of this study's research allowed it to discover how parents frequently used their parenting style to boost their children's academic success.

The correlation coefficient in this study's analysis demonstrated how to analyze linear relationships between two variables. A high $r$ correlation value indicates a strong link between the two variables under investigation, as well as the inverse. Using Pearson correlation analysis, this study will examine how parental style relationships are used by parents to improve their children's academic success.

Cohen (1988) and Pallant (2007) both give interpretations of correlation values, stating that if there is a high correlation between two variables, it is suggested that there may be a significant link between the two variables. In this study, researchers used the phrase "strong connection terms" to describe a high correlation in the data.

\section{Results and Discussion}

In this study, a total of 121 second-class MTs students participated as respondents. According to the findings of the questionnaire, 53 men (43.8\%) and 68 women $(56.2 \%)$ answered the questions. 
When looking at the composition of respondents, there were 34 Malay tribes (28.1 percent), 26 Minang ethnic groups (21.5\%), 39 Javanese tribes (32.2\%), and 22 Batak tribes (18.2\%). There were a total of 121 respondents mentioned in the MTs Ittihadul Muslimin Siak questionnaire.

\section{Culture and Tradition}

The distribution of responses to the question about what their parents' culture and traditions are like is shown in Table 4.2 below.

Table 4.2 Cultural Frequency and Tradition

\begin{tabular}{|c|c|c|c|c|c|c|c|c|c|c|c|c|}
\hline \multirow{2}{*}{$\begin{array}{c}\text { Item Culture } \\
\text { and } \\
\text { Tradition }\end{array}$} & \multicolumn{2}{|c|}{ STS } & \multicolumn{2}{|c|}{ TS } & \multicolumn{2}{|c|}{ KS } & \multicolumn{2}{|c|}{$\mathbf{S}$} & \multicolumn{2}{|c|}{ SS } & \multirow[b]{2}{*}{ Mean } & \multirow[b]{2}{*}{ SD } \\
\hline & $\mathbf{N}$ & $\%$ & $\mathbf{N}$ & $\%$ & $\mathbf{N}$ & $\%$ & $\mathbf{N}$ & $\%$ & $\mathbf{N}$ & $\%$ & & \\
\hline Culture 1 & 2 & 1.6 & 4 & 3.3 & 23 & 19.0 & 31 & 25.7 & 61 & 50.4 & 4.19 & 0.97 \\
\hline Culture 2 & 2 & 1.6 & 3 & 2.5 & 11 & 9.1 & 66 & 54.6 & 39 & 32.2 & 4.13 & 0.81 \\
\hline Culture 3 & 5 & 4.1 & 1 & 0.8 & 9 & 7.4 & 79 & 65.4 & 27 & 22.3 & 4.01 & 0.84 \\
\hline Culture 4 & 11 & 9.1 & 59 & 48.8 & 23 & 19.0 & 23 & 19.0 & 5 & 4.1 & 2.60 & 1.03 \\
\hline Culture 5 & 17 & 14.1 & 31 & 25.6 & 32 & 26.4 & 31 & 25.6 & 10 & 8.3 & 2.88 & 1.18 \\
\hline Culture 6 & 1 & 0.8 & 1 & 0.8 & 4 & 3.3 & 23 & 19.0 & 92 & 76.1 & 4.68 & 0.66 \\
\hline Culture 7 & 8 & 6.6 & 11 & 9.1 & 2 & 1.6 & 80 & 66.2 & 20 & 16.5 & 3.76 & 1.05 \\
\hline
\end{tabular}

Respondents who strongly agreed with cultural item 1 (my parents always advised me not to break the norms and culture adhered to by my family) accounted for 74 percent of those who replied (50.4\%). While 6 respondents (4.9\%) who replied did not agree or strongly disagree, the rest of the respondents were divided. Among those who replied that they strongly agree with cultural item 2 (my parents constantly enhance their activities with other family members), 39 people (32.2\%) said they always agree. However, five respondents (4.1 percent) said that they disagreed or strongly disagreed. Twenty-seven respondents (22.3\%) gave a very positive response to the cultural item 3, "My parents constantly talk about the ancestral customs that are still maintained." While 5 respondents (4.9\%) said they disagreed or strongly disagreed, the majority said they agreed. For four cultural elements, my parents advised me to carry on the work they were doing at the time, and as many as 5 respondents $(4.1 \%)$ indicated they strongly agreed with this. However, 70 respondents $(57.9 \%)$ said that they disagreed or strongly disagreed.

Regarding the first five cultural aspects, my parents have always taught me that following family customs performed by family members will help me achieve; as many as ten respondents $(8.3 \%)$ strongly agreed with this. While 48 respondents (39.7\%) said they disagreed or strongly disagreed, the majority of respondents said they agreed. My parents always stressed to me the importance of upholding our family's excellent reputation, and 92 respondents (76.1\%) said they strongly agreed with Cultural Items 6 and 7. However, just two respondents (1.6\%) indicated that they disagreed or strongly disagreed with the survey. When it came to cultural item 7 , which was about how my parents truly appreciate the culture and 
family custom that they received from their ancestors, as many as 20 respondents (16.5\%) said they strongly agreed. As a result, 19 respondents (15.7\%) said that they were opposed or strongly disagreed. The overall Mean item for this item is 3.75, which represents the formation of parental culture and tradition. The significance of parents' culture and tradition is quite significant.

Parenting in an Autoritative Style

The distribution of responses provided by respondents in response to the assertions made in the Oralitative Parenting Style questionnaire is shown in Table 4.3 below.

Table 4.3 Parenting Frequency in an Autoritatif Style

\begin{tabular}{|c|c|c|c|c|c|c|c|c|c|c|c|c|}
\hline \multirow{2}{*}{$\begin{array}{l}\text { Item } \\
\text { Autoritatif } \\
\text { Parenting } \\
\text { Style }\end{array}$} & \multicolumn{2}{|c|}{ STS } & \multicolumn{2}{|c|}{ TS } & \multicolumn{2}{|c|}{ KS } & \multicolumn{2}{|c|}{$\mathbf{S}$} & \multicolumn{2}{|c|}{ SS } & \multirow[b]{2}{*}{ Mean } & \multirow[b]{2}{*}{ SD } \\
\hline & $\mathbf{N}$ & $\%$ & $\mathbf{N}$ & $\%$ & $\mathbf{N}$ & $\%$ & $\mathbf{N}$ & $\%$ & $\mathbf{N}$ & $\%$ & & \\
\hline Autoritatif 1 & 1 & 0.8 & 7 & 5.8 & 23 & 19.0 & 81 & 66.9 & 9 & 7.4 & 3.74 & 0.71 \\
\hline Autoritatif 2 & 4 & 3.3 & 5 & 4.1 & 22 & 18.2 & 67 & 55.4 & 23 & 19.0 & 3.83 & 0.90 \\
\hline Autoritatif 3 & 3 & 2.5 & 11 & 9.1 & 13 & 10.7 & 72 & 59.5 & 22 & 18.2 & 3.82 & 0.92 \\
\hline Autoritatif 4 & 4 & 3.3 & 11 & 9.1 & 9 & 7.4 & 77 & 63.6 & 20 & 16.5 & 3.81 & 0.93 \\
\hline Autoritatif 5 & 2 & 1.7 & 2 & 1.7 & 5 & 4.1 & 87 & 71.9 & 25 & 20.7 & 4.08 & 0.68 \\
\hline Autoritatif 6 & 5 & 4.1 & 9 & 7.4 & 9 & 7.4 & 78 & 64.5 & 20 & 16.5 & 3.82 & 0.94 \\
\hline Autoritatif 7 & 8 & 6.6 & 22 & 18.2 & 19 & 15.7 & 71 & 58.7 & 1 & 0.8 & 3.29 & 1.00 \\
\hline Autoritatif 8 & 5 & 4.1 & 26 & 21.5 & 33 & 27.3 & 21 & 17.4 & 36 & 29.8 & 3.47 & 1.24 \\
\hline Autoritatif 9 & 9 & 7.4 & 31 & 25.6 & 17 & 14.0 & 49 & 40.5 & 15 & 12.4 & 3.25 & 1.19 \\
\hline
\end{tabular}

Through the formulation, it was discovered that autoritative item 1, namely my parents' care about my needs and feelings, showed that respondents who answered strongly agreed with as many as 9 students (7.4\%), answers were very disagreeing and disagreeing with as many as 8 students (7.4\%), answers were very disagreeing and disagreeing with as many as 8 students (7.4\%), answers were very disagreeing and disagreeing with as many as 8 students $(7.4 \%)$, and answers were very disagreeing and disagreeing with as many as 8 students (7.4\%). As a result of respondents' responses to the autoritative 2 items, my parents encouraged me to express my feelings and problems, and the results showed that respondents who strongly agreed were as many as 23 students (19.02\%), while respondents who strongly disagreed were as many as 9 students (7.4\%). Respondents' responses to the interactive question 3 revealed that as many as 22 students (18.2\%) strongly agreed, as many as 14 students disagreed, and as many as 14 students replied that they extremely disagreed (11.6\%). For the autoritative item 4, my opinion is always taken into consideration by parents when planning family activities (holiday or weekend activities). The results show that those who strongly agree accounted for as many as 20 students (16.5\%), those who disagree accounted for as many as 15 students (13.5\%), and those who disagree accounted for as many as 15 students (11.5\%). For authority item 5, parents always spend time with me, demonstrating that as many as 25 children (20.7\%) answered strongly agreeing, while four children (3.4\%) disagreed.

In the same way, in autoritative question 6, my parents treated me the same as other family members, demonstrating that respondents who replied strongly agreed included as 
many as 20 students (16.5\%), strongly disagreed with 14 students (11.5\%), and strongly agreed with none. For autoritative item 7, particularly, my parents frequently express to me how they feel about my excellent or bad behavior. I've displayed responses from as few as one student $(0.8 \%)$ who strongly agrees, and as many as thirty students $(24.8 \%)$ who respond extremely disrespectfully and disagree. For authority item 8, my parents described the reasoning for my desire to demonstrate, which resulted in responses from as many as 36 students (29.8\%) who strongly agreed, and responses from as many as 31 students who replied with extreme disagreement or disagreement (25.6\%). When it comes to autoritative item 9, my parents will make me feel comfortable and understood when I am frustrated by presenting responses from as many as 15 students (12.4\%) who strongly agree, and responses from as many as 40 students who strongly disagree and disagree (33.0\%). When evaluated Darui, the formulation of the parenting authority style for the mean value on average is 3.68. This significant authorization type authority is associated with a high mean value, as previously stated.

\section{Parenting in an Autoritarian Style}

Respondents' responses to the autoritarian parenting style are depicted in the following table (4.4).

Table 4.4 Parenting Frequency in an Autoritarian Style

\begin{tabular}{|c|c|c|c|c|c|c|c|c|c|c|c|c|}
\hline \multirow{2}{*}{$\begin{array}{l}\text { Item } \\
\text { Autoritarian } \\
\text { Parenting } \\
\text { Style }\end{array}$} & \multicolumn{2}{|c|}{ STS } & \multicolumn{2}{|c|}{ TS } & \multicolumn{2}{|c|}{ KS } & \multicolumn{2}{|c|}{$S$} & \multicolumn{2}{|c|}{ SS } & \multirow[b]{2}{*}{ Mean } & \multirow[b]{2}{*}{ SD } \\
\hline & $\mathbf{N}$ & $\%$ & $\mathbf{N}$ & $\%$ & $\mathbf{N}$ & $\%$ & $\mathbf{N}$ & $\%$ & $\mathbf{N}$ & $\%$ & & \\
\hline $\begin{array}{l}\text { Autoritarian } \\
1\end{array}$ & 31 & 25.6 & 34 & 28.1 & 14 & 11.6 & 27 & 22.3 & 15 & 12.4 & 2.68 & 1.39 \\
\hline $\begin{array}{l}\text { Autoritarian } \\
2\end{array}$ & 9 & 7.4 & 17 & 14.0 & 11 & 9.1 & 41 & 33.9 & 43 & 35.5 & 3.76 & 1.28 \\
\hline $\begin{array}{l}\text { Autoritarian } \\
3\end{array}$ & 33 & 27.3 & 29 & 24.0 & 31 & 25.6 & 12 & 9.9 & 16 & 13.2 & 2.58 & 1.34 \\
\hline $\begin{array}{l}\text { Autoritarian } \\
4\end{array}$ & 16 & 13.2 & 14 & 11.6 & 19 & 15.7 & 32 & 26.4 & 40 & 33.1 & 3.55 & 1.40 \\
\hline $\begin{array}{l}\text { Autoritarian } \\
5\end{array}$ & 27 & 22.3 & 22 & 18.2 & 21 & 17.4 & 39 & 32.2 & 12 & 9.9 & 2.89 & 1.34 \\
\hline $\begin{array}{l}\text { Autoritarian } \\
6\end{array}$ & 8 & 6.6 & 17 & 14.0 & 19 & 15.7 & 41 & 33.9 & 36 & 29.8 & 3.66 & 1.23 \\
\hline $\begin{array}{l}\text { Autoritarian } \\
7\end{array}$ & 41 & 33.9 & 39 & 32.2 & 35 & 28.9 & 4 & 3.3 & 2 & 1.7 & 2.07 & 0.96 \\
\hline $\begin{array}{l}\text { Autoritarian } \\
8\end{array}$ & 37 & 30.6 & 41 & 33.9 & 39 & 32.2 & 2 & 1.7 & 2 & 1.7 & 2.10 & 0.92 \\
\hline $\begin{array}{l}\text { Autoritarian } \\
9\end{array}$ & 35 & 28.9 & 60 & 49.6 & 14 & 11.6 & 10 & 8.3 & 2 & 1.7 & 2.04 & 0.94 \\
\hline $\begin{array}{l}\text { Autoritarian } \\
10\end{array}$ & 40 & 33.1 & 59 & 48.8 & 18 & 14.9 & 2 & 1.7 & 2 & 1.7 & 1.90 & 0.83 \\
\hline
\end{tabular}

There were as many as 15 students (12.4\%) who strongly disagreed with the autoritarian 1 items, while as many as 65 students strongly disagreed with the autoritarian 2 
items. In autoritarian 1 items, my parents always punish me by not allowing me to watch television or play my favorite game when I make a mistake (53.7\%). According to the authoritarian 2 items, my parents always reprimanded me when I did something wrong, with 43 students (35.5\%) responding strongly agreed, and as many as 26 students responding extremely disagreed (21.4\%). Students who strongly agreed with 16 students $(13.2 \%)$, students who answered very disagree, students who answered disagree, and students who answered strongly disagree. 62 students were found in the autoritarian 3 items. My parents always scolded and scolded me. The results showed that $(51.0 \%)$. The four objects in the authoritarian category are parents. I constantly bring up the things they have done to me, such as giving me responses from as many as 40 students (33.1\%) who answered "very much agreeing," "very disagreeing," and "disagreeing," and as many as 30 students (33.1\%) who answered "very disagreeing" and "disagreeing" (24.8\%). When it comes to the autoritarian 5 items, parents always bring up the old mistakes I have made in the past, for the reason that I will not repeat them. This shows that respondents who strongly agree with as many as 12 students (9.9\%), strongly disagree with as many as 49 students $(9.9 \%)$, and strongly disagree with as many as 12 students (9.9\%).

The autoritarian 6 items were always a source of constant reminders from my parents that they were my parents and that I needed to follow their instructions. The results of the survey revealed that respondents who strongly agreed included as many as 39 students (29.8\%), while those who strongly disagreed included as many as 25 students (20.6\%). My parents often pushed me to like whatever they liked when it came to the authoritarian 7 items, displaying respondents who replied very much agreeing with 2 students $(1.7 \%)$, extremely disagreeing with 2 students (1.7\%), and disagreeing with as many as 80 students (66.1\%). For the autoritarian 8 items, my parents would strike me if I do or say something they don't like. This indicates respondents who replied strongly agreed with as few as 2 students $(1.7 \%)$, very disagreed with 78 students, and strongly disagreed with as many as 2 students (1.7\%) (64.5\%). As for the autoritarian 9 items, my parents usually yelled at me when I did anything they didn't like, with as few as 2 students (1.7\%) strongly agreeing, as many as 95 students disagreeing, and as many as 2 students (1.7\%) severely disagreeing (78.5\%). As a kind of punishment for autoritarian items, I utilized snapping as a method of demonstrating that respondents who replied strongly agreed included as many as 2 kids (1.7\%), strongly disagreed and disagreed included as many as 99 students (97\%) (81.9\%). The average mean value of 2.72 is used to formulate the authoritarian parenting style as a formulation. This indicates that the authoritarian parenting style has a low mean value when compared to other parenting styles. 
INTERNATIONAL JOURNAL OF ACADEMIC RESEARCH IN PROGRESSIVE EDUCATION AND

DEVELOPMENT

Vol. 10, No. 4, 2021, E-ISSN: 2226-6348 @ 2021 HRMARS

Parenting in an Permisif Style

The distribution of responses to permissive parenting methods is seen in Table 4.5.

Table 4.5 Parenting Frequency in an Permisif Style

\begin{tabular}{|c|c|c|c|c|c|c|c|c|c|c|c|c|}
\hline \multirow{2}{*}{$\begin{array}{l}\text { Item } \\
\text { Permissive } \\
\text { Parenting } \\
\text { Style }\end{array}$} & \multicolumn{2}{|c|}{ STS } & \multicolumn{2}{|c|}{ TS } & \multicolumn{2}{|c|}{ KS } & \multicolumn{2}{|c|}{$S$} & \multicolumn{2}{|c|}{ SS } & \multirow[b]{2}{*}{ Mean } & \multirow[b]{2}{*}{ SD } \\
\hline & $\mathbf{N}$ & $\%$ & $\mathbf{N}$ & $\%$ & $\mathbf{N}$ & $\%$ & $\mathbf{N}$ & $\%$ & $\mathbf{N}$ & $\%$ & & \\
\hline $\begin{array}{l}\text { Permissive } \\
1\end{array}$ & 44 & 36.4 & 49 & 40.5 & 18 & 14.9 & 7 & 5.8 & 3 & 2.5 & 1.98 & 0.99 \\
\hline $\begin{array}{l}\text { Permissive } \\
2\end{array}$ & 36 & 29.8 & 51 & 42.1 & 15 & 12.4 & 18 & 14.9 & 1 & 0.8 & 2.15 & 1.04 \\
\hline $\begin{array}{l}\text { Permissive } \\
3\end{array}$ & 49 & 40.5 & 36 & 29.8 & 27 & 22.3 & 8 & 6.6 & 1 & 0.8 & 1.98 & 0.99 \\
\hline $\begin{array}{l}\text { Permissive } \\
4\end{array}$ & 41 & 33.9 & 43 & 35.5 & 23 & 19.0 & 9 & 7.4 & 5 & 4.1 & 2.12 & 1.09 \\
\hline $\begin{array}{l}\text { Permissive } \\
5\end{array}$ & 60 & 49.6 & 37 & 30.6 & 20 & 16.5 & 3 & 2.5 & 1 & 0.8 & 1.74 & 0.88 \\
\hline $\begin{array}{l}\text { Permissive } \\
6\end{array}$ & 12 & 9.9 & 11 & 9.1 & 29 & 24.0 & 53 & 43.8 & 16 & 13.2 & 3.41 & 1.14 \\
\hline $\begin{array}{l}\text { Permissive } \\
7\end{array}$ & 17 & 14.0 & 17 & 14.0 & 28 & 23.1 & 38 & 31.4 & 21 & 17.4 & 3.24 & 1.29 \\
\hline $\begin{array}{l}\text { Permissive } \\
8\end{array}$ & 17 & 14.0 & 19 & 15.7 & 15 & 12.4 & 39 & 32.2 & 31 & 25.6 & 3.40 & 1.39 \\
\hline $\begin{array}{l}\text { Permissive } \\
9\end{array}$ & 33 & 27.3 & 29 & 24.0 & 23 & 19.0 & 22 & 18.2 & 14 & 11.6 & 2.63 & 1.36 \\
\hline
\end{tabular}

For permissive item 1, my parents will not reprimand me if I make a mistake in indicating that respondents agreed with 3 students (2.5\%) but disagreed with as many as 93 kids (76.9\%). For the permissive 2 item, respondents who strongly agreed with as many as 1 student $(0.8 \%)$ responded extremely disagreeing and disagreed with as many as 87 students (71.9\%). For three permissible questions, I displayed respondents who strongly agreed with as little as one student $(0.8 \%)$ and respondents who strongly disagreed with 85 students (70.3\%). For the permissive four things, my parents never highlighted the errors. I did demonstrate that respondents strongly agreed with as many as five students (4.1\%), very disagreed with as many as 84 students, and disagreed with as many as five students (4.1 percent) (69.4\%). For the permissive five things, my parents never supported me, particularly in my research, where respondents strongly agreed with as little as one student $(0.8 \%)$ and strongly disagreed with as many as 97 students (80.2\%). For permissive item 6 , my parents usually prepare and wrap my school supplies. There were as many as 16 kids (13.2\%) who strongly agreed, and as many as 23 students who responded by either extremely disagreeing or strongly disagreeing (19.0\%).

Similarly, when I received a poor score on the lenient 7 question, my parents never chastised me. The exam revealed that as many as 21 students (17.4\%) strongly agreed, while as many as 34 students (28.0\%) strongly disagreed and disagreed. For the permissive eight items, my parents were unconcerned when I determined something, as seen by the presence of as many as 31 students (25.6\%) who strongly agreed, and as many as 36 students who strongly disagreed and disagreed (29.7\%). For permissive item 9, my parents ignored my 
DEVELOPMENT

Vol. 10, No. 4, 2021, E-ISSN: 2226-6348 @ 2021 HRMARS

research indicating that respondents agreed with as many as 14 students $(11.6 \%)$ and disagreed with as many as 62 students (71.3\%). The average mean for lenient parenting styles is 2.52. This means that their parenting style is lenient.

The Relationship Between Parental Style and Academic Achievement

The interpretation of the correlation between parenting style and academic success is shown in Table 4.6 below

Table 4.6: A Correlation Study of the Relationship Between Parenting Style and Academic Achievement

\begin{tabular}{lccc}
\hline \multirow{1}{*}{ Parenting Style } & \multicolumn{2}{c}{ Academic } & \\
& \multicolumn{2}{c}{ Achievement } & Interpretation \\
& $\boldsymbol{r}$ & $\boldsymbol{p}$ & \\
\hline Autoritatif Parenting Style & 0.519 & 0.009 & High \\
Autoritarian Parenting Style & 0.372 & 0.012 & Medium \\
Permissive Parenting Style & 0.307 & 0.001 & Medium \\
\hline
\end{tabular}

As shown in Table 4.5 above, there is a statistically significant relationship between parental authority style and student academic achievement $(R=0.519$ and $P 0.05)$. Parenting authoritarian style $(r=0.372$ and $P$ 0.05) has the strongest relationship with academic achievement $(r=0.519$ and $P$ 0.05). Their association with academic success is shown by simple coefficients and permissive parenting styles $(R=0.307$ and $p 0.05$, respectively), and it is represented by a simple coefficient. As a result, the zero hypothesis, which states that there is no link between parenting style (autorithative, autoritarian, and permissive) and the accomplishment of Ittihadul Muslimin MTs students, is rejected.

\section{Conclusion}

Student Parenting Style Profile

Parents' attitudes towards their children's academic successes, according to Gadeyne, Ghesquiere, and Onghena, are strongly influenced by the results of their children's educational achievements (2004). Families have a critical role in the development of their children's personality characteristics. According to Zulkifli et al. (2011), parents have an extremely crucial influence on the academic performance of their children. The attitude of both parents toward their children's education, according to Yusof (2003), is extremely significant in defining the value of success in terms of their academics. According to Arnold's (2008) remark, he has investigated the fact that the interaction between parents and students is an important factor in the growth of major pupils.

Consider the findings. The mean value for culture and tradition is a significant 3.75, which shows that the spread of responses provided by respondents is to agree with each item statement provided in the questionnaire that is distributed. This remark was confirmed by Giselle (2015), who stated that student accomplishment is an essential component of education. Parents must have a good parenting style in order to assist children in developing high intelligence for their academic areas. This style should constantly support student achievement and serve as a source of inspiration for him (Salleh et al. 2012). 


\section{The relationship between parental style and student academic achievement}

Dehyadegary, et. al (2012), discovered that parents play a significant impact in influencing the stage of academic success in teenagers. According to the findings of this research, there is a statistically significant link between parenting styles and academic success. The findings of the study analysis revealed a statistically significant link between parenting autoritatif style, parenting style autoritarian style, and permissive parenting style and academic success. The findings of this study indicate that the success or failure of students' academics is caused by the parenting style that is used and is not only influenced by other variables that have not been researched, such as the level of intelligence (IQ), emotional stability (EQ), genetics, self-quality and student personality, the role and impression of the teacher, and the influence of peers.

The findings of this study also reveal that parents are abandoning the parental authority style as compared to the parenting styles of autoritarian and permissive parenting styles. The findings of this study were influenced by the findings of Oryan \& Gastil (2013), who discovered that parents who use the parenting style of authority are respectful of their children and intimate with them while being tough with them. Based on the findings of the study, it can be concluded that parents who practice parenting authority style should not be able to tell their children's brilliant academic achievements, particularly in the final adolescent ranking, and that the choice of parenting styles, whether autoritarian or permissive, should not cause children to significantly succeed or fail. The findings of this study also supported the findings of Salleh et al (2012), who found that parents who have a Parentitative Parenting Style are extremely important in helping students achieve brilliance in the academic field and becoming a source of inspiration, as well as those who encourage student success. The findings of this study were corroborated by those of Aziladeh et al (2011), who found that an autoritatif parenting style is associated with higher levels of academic performance.

According to Fujiwara et al (2011), implementing a positive parenting program (Triple P) can alleviate the problem of children and adolescents' behavior (Fujiwara et al., 2011), as well as enhance high academic success (Jonathan et al., 2013). However, investigators anticipate that researchers will include numerous more elements, such as family-opening, including parents in the school program recommended, and the stage of kid intelligence. For the purpose of impressing the best parenting styles, parenting styles may be classified into three types: authority style, authoritarian style, and permissive style (Baumrind, 1966). Permissive parenting style, on the other hand, refers to parents who have an overly soft attitude toward their children, who meet their children's will rather than traditionally by considering children as mature individuals, and who may determine themselves so as not to impress in the form of pressure, supervision, or behavioral regulations Excellent conduct is strongly discouraged (Baumrind, 1991).

Children's academic success can be influenced by the variation in parenting methods that are used. The authorization style of authority has been shown to contribute positively to the learning process and the development of high-individual children, whereas the authoritarian and permissive style is thought to lean toward a passive impression, concessions, and pressure that affirms academic achievement (Baumrind, 1971). As a result, it is critical that parents acquire relevant information and expertise so that they may give better advice for the beneficial development of their children, particularly in the academic area. While the permissive style and the authoritarian style are regarded as inclined to provide a passive impression, concessions, and pressures that will affirm academic 
performance, the autoritatif force has helped favorably in the learning and creation of high personalities (Omar et al., 2011).

\section{Acknowledgement}

The author expressed his heartfelt appreciation to the Islamic University of Riau's research and community service institution for facilitating the implementation of the contract No.70 / Contract / LPPM-UIR / 5-2020 at Ittihadul Muslim Islamic Boarding School MTs as a media for data collection respondents through the deployment of the questionnaire.

\section{Corresponding Author}

Institute of Research and Community Service, Universitas Islam Riau, Jl. Kaharuddin Nasution No.113, Kota Pekanbaru, Riau Province 28284, Indonesia

Email: najmihayati@fis.uir.ac.id

\section{References}

Ang, R. P., \& Goh, D. H. (2006). Authoritarian Parenting Style in Asian Societies: A ClusterAnalytic Investigation. Contemporary Family Therapy Volume 28, pages 131-151. https://doi.org/10.1007/s10591-006-9699-y.

Arnold, D.H., Zeljo, A., \& Doctoroff, G.L. (2008). Parent Involvement In Preschool Predictors And The Relation Of Involvement To Prelitery Development. School Psychology Review, 37(1), 74-90.

Bakar, M. F. A. (2007). Hubungan Antara Pendidikan Agama, Keseimbangan Kognitif dan Tingkahlaku Positif Di Kalangan Pelajar Darjah Khas Sekolah Agama Di Johor Bahru. Tesis UTM: Fakulti Pendidikan

Baldwin, J. M., Karlhorn, \& Breese. (1945). Mental Development In The Child And Race, Methods And Processess. New York: Macmillan

Baldwin, D. R., Mclntyre, A., \& Hardaway, E. (2007). Perceived parenting styles on Collegestudents' Optimism. Journal of College Student, 41, 550-557.

Baumrind, D. (1966). Effects Of Authoritative Parental Control On Child Behavior. Child Development, 37, 887-907.

Baumrind, D. (1967). Child Care Practices Anteceding Three Patterns Of Preschool Behavior. Genetic Psychology Monographs, 75, 43-88.

Baumrind, D. (1971). Child Care Practices Antecending Three Patterns Of Preschool Behaviour. Genetic Psychology Monographs, 75, 43-88

Baumrind, D. (1989). Rearing Competent Children In W. Damon (Ed). Child Development Today And Tomorrow (349-378), San Francisco : Josey Bass

Baba, S. (2007). Peranan Sistem Pendidikan Dalam Pembangunan Keluarga Islam. MPH Group Publishing Sdn Bhd : Selangor

Bee, M. N. A., \& Herman. I. (1995). Membina Kesejahteraan Remaja. Tekno Edar : Selangor

Clark, R. D., \& Shields, G. (1997). Family Communication and Delinquency. Adolescence, 32(125), 81-92.

Dawi, A. H. (2009). Sekolah Dan Masyarakat. Tanjong Malim: Quantum Books Amla Salleh, Noriah Ishak, Zuria Mahmud, Ramlee Mustapha, M. Mokhtar, \& S.

Dehyadegary, E., Divsalar, K., Esmaeili, N. S., Sadr, A. J., \& Askari. F. (2012). Academic Engagement As A Mediator In Relationship Between Parenting Style And Academic 
Achievement Among Adolescents In Sirjan-Iran. Life Science Journal 2012;9(4). http://www.lifesciencesite.com

Elias, H., \& Yee, T. H. (2009). Relationship between Perceived Paternal and Maternal Parenting Styles and Student Academic Achievement in Selected Secondary Schools. European Journal of Social Sciences, 9(2).

Fabes, R., \& Martin, C. L. (2003). Exploring Child Development. 2rd Ed. USA: Allyn \& Bacon. Pearson Education, inc.

Fujiwara, T., Kato, N., \& Sanders, M. R. (2011). Effectiveness of Group Positive Parenting Program (Triple P) in Changing Child Behavior, Parenting Style, and Parental Adjustment: An Intervention Study in Japan. Journal of Child and Family Studies, 20, 804-813.

Gadeyne, E., Ghesquiere, P., \& Onghena, P. (2004). Longitudinal Relations Between Parenting And Child Adjustment In Young Children. Journal of Clinical Child and Adolescent Psychology, 22, 347-358.

Giselle, F. (2015). The Relationship Between Parenting Style and The Level of Emotional Intelligence in Preschool-Aged Children. PCOM Psychology Dissertations. 341.

Harun, L. M. (2007). Asas Kaunseling keluarga. Shah Alam : Universiti Teknologi Mara

Hayes, N. (2000). Doing Psychological Research: Gathering And Analyzing Data/Nicky Hayes. ISBN 0-335-20379-5 (pbk.) 1. Psychology-Research-Methodology.

Hines, E. M., \& Holcomb-McCoy, C. (2013). Parental Characteristics, Ecological Factors, And The Academic Achievement Of African American Males. Journal of Counseling \& Development. 91, 68-77.

Irmawati. (2002). Motivasi Berprestasi Dan Pola Pengasuhan Pada Suku Bangsa Batak Toba Di Desa Parparean II Dan Suku Bangsa Melayu Di Desa Bogak (Studi Etnopsikologi). Universitas Indonesia, Jakarta. Retrieved from http://lib.ui.ac.id/ file?file=pdf/abstrak20342483.pdf tanggal 1 Mei 2017.

Irmawati. (2007). Keberhasilan Suku Batak Toba (Tinjauan Psikologi Ulayat). Disampaikan Pada Seminar Psikologi Dan Budaya, 24 Maret 2007. Program Studi Psikologi Fakultas Kedokteran Univer-sitas Sumatera Utara.

Jeynes, W. H. (2007). The Relationship Between Parental Involvement And Urban Secondary School Student Academic Achievement: A Meta-Analysis. Urban Education, 42(1), 82110.

Munji, S. H., \& Redzuan, M. (1990). Penghantar Psikologi. Petaling Jaya: Fajar Bakti Sdn Bhd Nauly, M., \& Fransisca, V. (2015). Identitas Budaya Pada Mahasiswa BatakToba Yang Kuliah Di Medan. Jurnal Psikologi Ulayat: Indonesian Journal of Indigenous Psychology, 2(1), 364-380. doi: 10.24854/ jpu12015-32.

Nurdiani, P. R. (2019). Konsep Institusi Keluarga Dalam Islam. Tarbiyah Wa Ta'lim: Jurnal Penelitian Pendidikan \& Pembelajaran. 6(3). Https://Doi.Org/10.21093/Twt.V6i3.1726

Noorezatty, M., Ang Chooi Leng., \& Zurni Omar. (2004). Model Penentu Prestasi Pelajar Program Kerjasama UUM-IPTS. Fakulti Sains Kuantitattif: UUM Sintok.

Norsayyidatina, C. R. (2011). Peranan Keorang Tuaan Dan Hubungannya Dengan Kesejahteraan Psikologi Dalam Kalangan Remaja Cemerlang Akademik. Tesis Sarjana. Fakulti Pendidikan, UKM

Omar, N. H., Manaf, A. A., \& Ayob, A. S. (2012). Pengujian Model Gaya Keorang Tuaan Baumrind Ke Atas Prestasi Akademik Pelajar Sekolah Menengah. Jurnal Sains Sosial Dan Kemanusiaan. Fakulti Sains Sosial Dan Kemanusiaan, UKM 
DEVELOPMENT

Vol. 10, No. 4, 2021, E-ISSN: 2226-6348 @ 2021 HRMARS

Omar, H. (2008). Peranan Dan Cabaran Yayasan Pembangunan Keluarga Masa Kini Dan Akan Datang. Kertas Kerja Seminar Kaunseling. Skudai : UTM

Oryan, S., \& Gastil, J. (2013). Democratic Parenting: Paradoxical Messages In Democratic Parent Education Theories. International Review of Education, 59, 113-129.

Pallant, J. (2007). SPSS Survival Manual: A Step Bt Step Guide To Data Analysis Using SPSS For Windows. $3^{\text {rd }}$ Edition. Australia: Ligare Book Printer Sydney.

Rathakrishnan, B., \& Rahim. R. A. (2008). Etnik Dan Gaya Keorang Tuaan Ke Atas Penglibatan Pelajar Dalam Penagihan Dadah: Satu Kajian Awal Di Sabah. Jurnal Antidadah Malaysia. 123-141

Salleh, M. J., Kamin, M., \& Henry, J. F. (2012). Kajian Terhadap Faktor-Faktor Mempengaruhi Prestasi Pelajar Dalam Penilaian Menengah Rendah Di Sabah. Labuan International Conference on Educational Research - LICER 2012. Financial Park Complex Wilayah Persekutuan Labuan. 5-7 July 2012.

Sedyawati, E. (2007). Budaya Indonesia: Kajian Arkeologi. Jakarta: Raja Grafindo Persada.

Sedyawati, E. (2010). Budaya Indonesia: Kajian Arkeologi, Seni, Dan Sejarah. Perpustakaan Pusat UNSIMAR.

Simanjuntak, B. A. (2009). Konflik Status Dan Kekuasaan Orang Batak Toba- Bagian Sejarah Batak. (Edisi Revisi). Jakarta: Yayasan Pustaka Obor Indonesia

Sokol-Katz, J., Dunham, R., \& Zimmerman, R. (1997). Family Structure Versus Parental Attachment in Controlling Adolescent Deviant Behaviour: A Social Control Model. Adolescence, 32(125), 199-215.

Suwardi. (2007). Kebudayaan Melayu. Pekanbaru: Kampus Akademik Pariwisata Engku Puteri Hamida.

Syukur, A. (2012). Studi Budaya di Indonesia. Bandung: Pustaka Setia.

Yahaya, A. (2007). Pembentukan Keluarga Yang Bahagia: Cara mengatasi masalah untuk kecemerlangan keluarga. Skudai : UTM

Yahaya, A., \& Bahari, M. S. (2010). Gaya Asuhan Orang Tua Remaja Terhadap Tingkahlaku. Dalam talian: http://www.eprints.utm.my.

Yusof, M. (2000). Isu-Isu Dan Permasalahan Masa Kini: Punca-Punca Dan Cara Membantu Mereka. http://www.teenet.com.my/art20.html

Wiersma, W. (2000). Research Methods In Education. Boston: Allyn and Bacon Williams, W. 2008. The Relationship Between Parenting Practices, Socioeconomic Status, and Ethnicity to the Academic Achievement of High School Students. http://www.allfreeessays.com/essays/Relationship-Between-

ParentingPracticesSoeconomic-Status/11502.html.

Zin, S. A. (2005). Gaya Keorang tuaan Di Kalangan Orang tua Kanak-Kanak Tadika Kemas Kawasan Cheras. Projek Sarjana Pendidikan: Fakulti Pendidikan, UKM

Yusof, Z. (2003). Hubungan Antara Latar Belakang Keluarga Dengan Prestasi Akademik Pelajar Melayu Dalam PMR. Tesis Sarjana Sains : Universiti Utara Malaysia

Zulkifli, A. H., Jamilah O., Aminah A., \& Ismi A. I. (2011). Hubungan Antara Penglibatan Orang Tua Dan Prestasi Akademik Pelajar Miskin Di Selangor. Journal of Islamic and Arabic Education. 